\title{
A PROFILE OF THE REGISTERED NURSE TUTOR IN THE RSA
}

\author{
H. I. L. Brink
}

\section{Introduction}

It is just over six and a half decades ago that the first qualified sister tutor (now designated nurse tutor) was appointed in this country. South Africa's first sister tutor, a single young female, was recruited from England and held the distinction of being a gold medalist of the Nightingale School of St. Thomas Hospital London and a qualified sister tutor from King's College, University of London. (Searle. 1964). She was thus qualitatively well prepared in both nursing and teaching. The standard of her tutor's qualification was on a par with that of other teacher's malifications in the country at that time

21) and she was an experienced nurse. She was well suited to the responsibilities allocated to her, namely to take charge of the probationer nurses of the newly established Preliminary Training School for nurses of the Johannesburg Hospital and to give lectures and demonstrations on nursing matters.

Almost a quarter of a century later in 1945, when the first College of Nursing was established in this country and just before the South African Nursing Council (SANC) resolved to institute an additional register for sister tutors, the number of qualified practising sister tutors in the country had risen to twenty-nine. (Searle 1964a: 189). With such small numbers common characteristics of tutors could still be identified and recorded, and information including the personal and educational background on many of these early pioneers can be found in the rature (Harrison 1979: Searle 1964).

1 rom the literature the following profile emerges. These early pioneer tutors were all experienced nurses, who were highly thought of in the profession. They were motivated teachers who had undergone their tutor training at considerable financial sacrifice. They were all females mostly in their late twenties or early thirties and unmarried and the majority used their teaching experience as a stepping stone to higher posts in nursing administration. Before they got there however, they had all rendered significant services to nursing education.

In 1983, when preparations were well ahead for the transition of the nursing education system of this country into a university-linked secondary education system, the number of qualified nurse tutors whose names were entered into the SANC additional register for tutors, was 1502 (SANC 28.7.83). With such large numbers identification of common characteristics of tutors was of course no longer possible. While information such as names and addresses, gender and population or language group of all persons registered as tutors could be

\begin{tabular}{l} 
Abstract \\
The purpose of this study was to \\
explore and describe selected demo- \\
graphical, biographical, educational \\
and professional background \\
characteristics of the registered nurse \\
tutors in the RSA and to construct a \\
profile of the characteristics. Such a \\
profile could provide a baseline for \\
future studies and evaluation \\
concerning registered nurse tutors. \\
Data were collected from a random \\
proportional stratffied sample of 233 \\
registered nurse tutors from a total of \\
I3I2 registered tutors whose names \\
appeared on the SANC register. A \\
questionnaire developed by the \\
researcher and based on and adopted \\
from a questionnaire from the Research \\
Triangle Institute USA on the \\
registered nurse in the USA, was used \\
for data collection. The data were \\
analysed and from the findings a profile \\
of the registered nurse tutor in the RSA \\
was constructed. \\
Uittreksel \\
Die doel van hierdie studie was om \\
geselekteerde demografiese, biografiese, \\
opvoedkundige en professionele \\
agtergrond eienskappe van die \\
geregistreerde Verpleegdosent in die \\
RSA te identifiseer en te beskryf, en om \\
n profiel van hierdie eienskappe op te \\
stel. So in profiel sal as basis vir verdere \\
studies en evaluering met betrekking tot \\
die geregistreerde verpleegdosent kan \\
dien. Data is ingesamel van 'n \\
ewekansige, proporsionele, gestra- \\
tifiseerde steekproef van 233 \\
geregistreerde verpleegdosente vanuit 'n \\
totaal van I 312 geregistreerde dosente \\
wie se name op die SA VV registers \\
verskyn. 'n Vraelys gebaseer op die van \\
die Research Triangle Institute, VSA \\
oor die geregistreerde verpleegkundige \\
in die VSA is deur die navorser \\
ontwikkel en gebruik om data te \\
versamel. Die gegewens is geaniliseer en \\
in profiel van die geregistreerde dosen: \\
in die RSA is opgestel. \\
\hline
\end{tabular}

obtained from the SANC register, no information on educational or professional background and experience was available from the register or could be traced from any other published literature or record. At this point of time such information would have been useful. Doubts and concerns were being voiced in several nursing circles as to whether the current nurse tutors had sufficient background experience and advanced knowledge to cope with the demands of the time and the knowledge explosion. Questions such as, are the nurse tutors qualifications on a par with those of other tertiary educators in the country? are they engaging in continuing education to upgrade their qualifications? are they in a position to enact the scholarly role expected of tertiary educators? are they maintaining contact with the practical realities of nursing through involvement in the clinical field? were being asked.

A need for a systematic investigation of the nurse tutor in the RSA was therefore identified. Findings from such an investigation would provide factual information to verify or dismiss the concerns that were being expressed. Furthermore such information might be valuable to nurse leaders to identify deficiencies and needs in respect of nursing education to-day and could provide a baseline for future studies and evaluations concerning the registered nurse tutors.

This report describes some of the findings of part one of the investigation carried out in 1983-84 on the registered nurse tutor in the RSA.

\section{The purpose of the study}

The study referred to in this report was undertaken to explore and describe selected demographical, biographical, educational and professional background characteristics of the registered nurse tutors in the RSA and to construct a profile of the characteristics.

\section{Definition of terms}

Profile as used in this report refers to an outline or schematic description of the main features or characteristics of a set of individuals (a sample of registered tutors).

\section{Registered nurse tutor}

Throughout this report the concept "registered nurse tutor" is viewed in a broad sense and refers to all professional nurses who have had the additional qualification of nurse tutor entered behind their name in the SANC register for tutors, regardless of whether they are actually engaged as teachers or not.

\section{Population and Sample}

All persons whose names appeared on the SANC register for tutors on July 28,1983 and who were residing within the borders of the RSA formed the population. From the total population of 1312 registered nurse tutors residing within the borders of the RSA (another 190 from the total of 1502 names listed in the register resided outside the borders of the RSA) a proportional stratified sample of 451 based on population group and gender was randomly selected. This constituted a 39,39 percent sample fraction. Two-hundred and thirty-three registered tutors $(17,5 \%$ of the total population) eventually participated in 


\begin{tabular}{|c|c|c|c|c|c|c|}
\hline & \multicolumn{2}{|c|}{ Total Population } & \multicolumn{2}{|c|}{ Selected Sample } & \multicolumn{2}{|c|}{ Participating Sample } \\
\hline & Female & Male & Female & Male & Female & Male \\
\hline Asiatic & 22 & 3 & 9 & 3 & 6 & 1 \\
\hline Black & 250 & 9 & 83 & 9 & 41 & 4 \\
\hline Coloured & 102 & 2 & 34 & 2 & 13 & 1 \\
\hline $\begin{array}{l}\text { White- } \\
\text { Afrikaans }\end{array}$ & 547 & 23 & 182 & 9 & 96 & 5 \\
\hline $\begin{array}{l}\text { White- } \\
\text { English }\end{array}$ & 351 & 3 & 117 & 3 & 64 & 2 \\
\hline Total & $\begin{array}{l}1272 \\
1\end{array}$ & 40) & $(425$ & 26) & $(220$ & 13) \\
\hline
\end{tabular}

the study. Table I provides more details of the total population, selected sample and participating sample.

\section{The Research Instrument}

With respondents widely dispersed throughtout the RSA the self-administered mailed questionnaire was considered to be the most suitable instrument to gather data from the selected sample. The questionnaire was developed by the researcher Part 1 of the questionnaire (the part pertaining to this report) contained 74 items requesting background information such as age, sex, marital status, educational background, years of experience in nursing and nursing education and so on. The items were based on a National Sample Survey of registered nurses in the $U S A$ questionnaire developed by the Research Triangle Institute, but were adapted to the local situation. A number of items specific to the South African nursing situation were added. Most of the items were of the forced-choice type and required only check marks as responses. Spaces were provided for any additional comments the respondents cared to make.

The questionnaire was pretested on a representative convenience sample of 20 registered nurse tutors and was also scrutinised by a panel of experienced nurse educators and scholars of the profession. It was considered to have content and face validity.

\section{Data collection}

The questionnaire together with a covering letter requesting the nurse tutors participation in the study and guaranteeing anonymity and confidentiality, and a selfaddressed stamped envelope was mailed to each of the 451 registered nurse tutors selected for the sample during October 1983. During December 1983 reminders were sent to sample members. By January $10,1984,255$ questionnaires of which 233 were usable had been returned.

\section{A nalysis of data}

Each of the 233 completed usable questionnaires was edited and coded. Data were organised and categorised, frequency counts were done and percentages of multiple choice answers were calculated. From this analysis the following profile of the registered nurse tutor of the 1980's emerged.

\section{Findings}

\section{DEMOGRAPHICAL AND BIOGRAPHICAL DATA}

These data include population group and gender, employment status, age and marital status and dependants.

\section{Population groups and gender}

As reflected in Table I, the total registered nurse tutor population of the 1980 's is still predominantly female. Only three percent is male. Roughly 2 percent belong to the Asiatic population group, 19,7 percent are Black, 7,9 percent Coloured, 43,4 percent White Afrikaans and 26,98 percent White English.

\section{Employment status}

Of the 233 respondents 87 percent are in full-time employment, 4 percent in parttime employment and 9 percent are not employed or were retired. Only 60 percent of the respondents are employed as teachers of nursing, while 31 percent are employed in a capacity other than teaching.

\section{Age}

The age distribution of the registered nurse tutor ranges from below 25 years to over 55 years, with only 1 respondent $(0,4 \%)$ below the age of 25 and $27(11,6 \%)$ above the age of 55. On the whole, registered nurse tutors are chronologically mature women, with those in other than teaching posts tending to be somewhat older than their counterparts in teaching posts. Almost one-half of the non-teaching group $(46 \%)$ is above the age of 45 , while 28 percent of the teaching group is found in this age group. Of the latter group more than a half $(51 \%)$ fall in the $35-44$ age groups. The median age of the teaching group is 40 years against that of 43,2 years for the non-teaching group.

\section{Marital status and dependants}

Unlike the nurse tutors of the pre-world war 2 era who were mostly single wome without dependants, only 31 percent of the registered nurse tutors of the 1980's have never been married and only 35 percent have no dependants.

\section{EDUCATIONAL BACKGROUND}

These data include background of mathematics and science, type of basic nursing programme completed and type of programme completed to first register as nurse tutor, participation in continuing formal education and additional postregistration courses.

Background of mathematics and science Only 39,9 percent of registered nurse tutors have a matriculation level background in mathematics, and only one-third of the group has a matriculation background of physical science and chemistry.
TABLE 2: AGE DISTRIBUTION OF REGISTERED NURSE TUTORS EXPRESSED IN PERCENTAGE

$\begin{array}{cccccc}\text { Age } & <\mathbf{2 5} & \mathbf{2 5 - 3 4} & \mathbf{3 5 - 4 4} & \mathbf{4 5 - 5 4} & >\mathbf{5 5} \\ \begin{array}{c}\text { teaching group } \\ \mathrm{n}=142\end{array} & 0,7 & 21 & 51 & 20 & 8 \\ \begin{array}{c}\text { non-teaching group } \\ \mathrm{n}=91\end{array} & - & 17 & 37 & 28 & 18 \\ \begin{array}{c}\text { total group } \\ \mathrm{n}=233\end{array} & 0,4 & 19,7 & 45,5 & 22,7 & 11.6\end{array}$

TABLE 3: MARITAL STATUS AND DEPENDANTS OF REGISTERED NURSED TUTORS EXPRESSED IN PERCENTAGE

$\begin{array}{ccccc}\begin{array}{c}\text { Teaching group } \\ \mathrm{n}=142\end{array} & \begin{array}{c}\text { Never } \\ \text { married }\end{array} & \begin{array}{c}\text { Now } \\ \text { married }\end{array} & \begin{array}{c}\text { Previously } \\ \text { married }\end{array} & \begin{array}{c}\text { 1 or more } \\ \text { dependants }\end{array} \\ \begin{array}{c}\text { Non-teaching group } \\ \mathrm{n}=91\end{array} & 30 & 55 & 13 & 68 \\ \begin{array}{c}\text { Total group } \\ \mathrm{n}=233\end{array} & 33 & 56 & 13 & 59 \\ \end{array}$


TABLE 4: TYPE OF NURSING PROGRAMME COMPLETED FOR REGISTRATION AS A NURSE. $n=233$

\begin{tabular}{lrr} 
Programme & $\mathbf{n}$ & \multicolumn{1}{c}{$\%$} \\
SANC Diploma & 195 & 83,7 \\
Bachelors degree & 29 & 12,4 \\
Other & 7 & 3,0 \\
Unknown & 2 &, 8 \\
Total & 233 & 99,9
\end{tabular}

Type of basic nursing programme completed for registration as a nurse

The greater majority of registered nurse tutors have completed their basic nursing programnme at diploma level. Of this group of respondents $195(83,7 \%)$ have completed the SANC diploma and 7 $(3,0 \%)$ other diploma or certificate programmes, bringing the total number of tutors with a non-degree basic nursing lification to $202(86,7 \%)$. The other grammes include Medical Council certificates, which had been obtained before the days of the SANC, a University diploma and Certificates obtained overseas.

Type or programme completed to first register as nurse tutor and basis on which tutor studies were undertaken

Almost four-fifths of the group $(79,4 \%)$ followed the University diploma programme leading to nurse tutor registration, while $31(13,3 \%)$ obtained their tutor registration with a postregistration bachelors degree. $8(3,4 \%)$ with a masters degree and a further $8(3,4 \%)$ by means of additional single subjects following a degree course. Of the total group only $61(26,2 \%)$ were graduates at the time they registered as a tutor, 45 $(19,3 \%)$ held one degree and $16(6,9 \%)$ two degrees, while $172(73,8 \%)$ had received both basic and post-basic qualifications at diploma level.

Seventy-seven percent of the registered nurse tutors under study had completed their tutor studies on a full-time basis and had obtained substantial financial assistance towards their studies from employing authorities. For the majority of the group this included study leave on full pay and payment of all tuition fees. Of the remaining 23 percent who had undertaken their tutor studies on a part-time basis, slightly less than two-thirds $(61,5 \%)$ had completed their study through UNISA. All respondents who had obtained their nurse tutor qualification through degree studies or by means of single subjects had studied part-time, while all respondents holding diploma qualifications, with the exception of 4 , who had completed their studies through UNISA had studied full-time. Only ten percent of the total group financed themselves for their tutor qualification.

All but $0,9 \%$ of the respondents have. obtained their tutor qualifications in this country.

\section{Participation in continuing formal education}

Less than one-half of the registered nurse tutors $(47 \%)$ had availed themselves of existing opportunities to further their studies in either nursing education or another field, after completion of their studies to register as a tutor. Thirty-eight percent had completed a bachelors or

\section{TABLE 5: TYPE OF PROGRAMME COMPLETED TO FIRST REGISTER AS A} NURSE TUTOR

\section{Togramme}

University Diploma

Post-registration

bachelors degree

Masters degree

Additional single

subjects

Unknown

Total

\begin{tabular}{cc}
\multicolumn{2}{c}{ Graduates } \\
n & $\%$ \\
14 & 48,2 \\
8 & 27,2 \\
7 & 24,1 \\
& \\
- & - \\
\end{tabular}

No
n
17
2



20

\begin{tabular}{cr}
\multicolumn{2}{c}{ Non-graduat } \\
$\mathbf{n}$ & $\%$ \\
171 & 84 \\
& \\
23 & 11 \\
1 & 0 \\
8 & 3 \\
- & - \\
203 & 99
\end{tabular}

\section{Total group}

$\begin{array}{cc}\text { n } & \% \\ 185 & 79,4\end{array}$

84,2

11,3

0,4

31

8

13,3

3,9

99,8
8

233

3,4
3,4
0,4
99,9

higher degree, 24 percent in nursing and 14 percent in another field, while 9 percent had completed a diploma, certificate or single subjects, 4,3 percent in nursing and 3 percent in another field. The remaining 1,7 percent did not specify the nature of their further study. The registered nurse tutor with a diploma as highest qualification still remains in the majority $(52 \%)$.

Of the 14 percent of nurse tutors who had completed degrees in another field than nursing $3,4 \%$ had completed a $\mathrm{BA}$ degree, $3,4 \%$ a B.Soc. Science, $0,8 \%$ a B.Admin., $0,4 \%$ a B.Sc., $1,2 \%$ a B.A. Hons (Psychology), 1,2\% a B.A. Hons

Sociology, $1,2 \%$ an M.A. Sociology and $0,8 \%$ an M.A. Psychology, $0,8 \%$ D.Ed. and $0.4 \%$ a Ph.D.

A number of registered nurse tutors were still engaged in studies towards a bachelors or higher degree at the time of the survey. The greater majority $(21,4 \%)$ were studying towards a bachelors degree while $6,4,4,2$ and 3 percent respectively were studying at Honours, Masters and doctoral level.

The projected percentage of registered nurse tutors holding a bachelors degree as minimum academic qualification should therefore increase to 69,4 percent when those tutors who are currently studying towards first bachelors degree complete their studies (at the time of publication of this report, this should already have materialised).

A variety of factors prevented more than half $(53 \%)$ of the registered nurse tutors from continuing with further formal studies, the most important (frequent) ones that were cited were a too heavy workload and family responsibilities.

\section{Additional post-registration courses}

From Table 7 it is noted that less than onequarter of the registered nurse tutors $(20,2 \%)$ have not followed an additional post-registration course in nursing, while 76 percent have completed at least one post-registration course in addition to the tutor course.

Nursing administration appears to be the most popular course, followed by Community Health with 48 percent holding the former qualification and 47 percent the latter. Advanced Clinical certificates representing a variety of nursing specialties are held by 16,6 percent of tutors. Nursing Specialties in which these certificates have been obtained are in rank-order from most to least; operating

\begin{tabular}{|c|c|c|c|c|}
\hline \multirow[b]{2}{*}{ Qualification } & \multicolumn{2}{|c|}{$\begin{array}{c}\text { At time of registration } \\
\text { as tutor }\end{array}$} & \multicolumn{2}{|c|}{$\begin{array}{l}\text { Since registration as } \\
\text { tutor at time of survey }\end{array}$} \\
\hline & $\mathbf{n}$ & $\%$ & $\mathbf{n}$ & $\%$ \\
\hline \multicolumn{5}{|c|}{ Post-registration tutor } \\
\hline Diploma & 185 & 79,4 & 121 & 52,0 \\
\hline Bachelors degree & 39 & 16,0 & 75 & 32,0 \\
\hline Honours degree & - & - & 15 & 6,4 \\
\hline Masters degree & 8 & 3,4 & 16 & 6,8 \\
\hline Doctorate & - & - & 6 & 2,6 \\
\hline Unknown & 1 & 0,4 & - & - \\
\hline
\end{tabular}

\begin{tabular}{|l|cc}
\hline \multicolumn{3}{|c|}{ TABLE 7: NUMBER OF ADDITIONAL } \\
POST-REGISTRATION COURSES \\
COMPLETED REGISTERED NURSE \\
\multicolumn{3}{|c}{ TUTORS (n = 233) } \\
Number of & \multicolumn{2}{c}{ Respondent } \\
post-registration courses & n & $?$ \\
None & 47 & 20,2 \\
One & 88 & 37,8 \\
Two & 75 & 32,2 \\
Three or more & 15 & 6,4 \\
Unknown & 8 & 3,4 \\
\end{tabular}


theatre, paediatrics, orthopaedics, intensive care nursing, advanced midwifery and neonatology, advanced psychiatric nursing and advanced clinical care

\section{PROFESSIONAL BACKGROUND AND EXPERIENCE}

These data include years of clinical nursing experience positions held in the clinical field, teaching experience, place of one employment and post held, time spent on teaching and enactment of scholarly role.

\section{Clinical nursing experience of registered}

\section{tutors}

As indicated in Table 8 the number of registered nurse tutors with limited clinical experience is small. Not even 20 percent had two or less years of clinical nursing experience when registering as a tutor, while 80 percent had more than three years and 61,8 percent more than five years of experience in the clinical field.

TABLE 8: YEARS OF CLINICAL EXPERIENCE BEFORE REGISTERING AS A TUTOR

\begin{tabular}{lrr} 
Years of experience & \multicolumn{1}{c}{$\mathbf{n}$} & $\%$ \\
$<$ I year & 5 & 2,1 \\
1 - 2 years & 41 & 17,6 \\
3 - 4 years & 43 & 18,5 \\
5 years and more & 144 & 61,8
\end{tabular}

\section{Fields of experience}

The nature of the clinical experience obtained is typically in a variety of areas. Seventy percent have gained experience in both medical and surgical areas and another 30 percent in specialised branches of these fields. Twenty percent have had experience in nursing administration and 9 percent as clinical teachers, while only 14 percent have had experience as community health or psychiatric nurses

\section{Positions held in the clinical field}

Fifty five percent of the registered nurse tutors held relatively senior positions in the services, ranging from senior sister to senior matron before doing the tutors course. Only $1,3 \%$ had had no clinical experience as registered nurse, while the remaining 43,7 percent had held sisters posts before becoming tutors.

\section{Teaching experience since tutor registration}

A very small group ( 7,7 percent) has not had any teaching experience at all since qualifying as a tutor. Included in this group are matrons, sisters in general nursing areas, and in child psychiatry and housewives. Almost one-half of the group $(46,3 \%)$ taught for five years or longer, while more than one-third $(37,7 \%)$ has had 1 - 4 years of teaching experience.

The greater majority of tutors $(76,7 \%)$ have taught pre-registration students in hospital and college setting while one-half have also taught pupil nurses in hospital and College setting, and 15 percent nursing students at a university. A small group
$(4,7 \%)$ have taught at a technicon, in inservice education programmes or paramedicals.

\section{Place of employment and posts held}

One-third of the registered nurse tutors are employed in nursing colleges, 32 percent in hospitals, 11 percent in universities and technicons and almost one-quarter in a wide variety of other fields, including the Head Offices of Provincial and State Hospital and Health Services respectively. Local Authority areas, Old Age Homes, Community Health Services, Industry and Commerce.

Of the registered nurse tutors in teaching posts, slightly more than one-third hold senior positions such as professor $(2 \%)$ principal of nursing colleges $(7 \%)$, senior lecturer $(3 \%)$ and senior tutor $(25 \%)$. The registered nurse tutors in non-teaching posts are found in a great variety of posts, ranging from Director and DeputyDirector of nursing, chief and senior nursing service manager to professional officers, ward sisters and researchers.

\section{Time spent on teaching and teaching-}

\section{related activities}

With the exception of two percent of registered nurse tutors in teaching posts, all tutors in teaching posts appear to spend far more than 40 hours a week on teaching and teaching-related activities. The time spent on specific activities varies according to work situation and rank. For the majority of nurse teachers, classroom teaching is a major activity. More than one-quarter $(26,5 \%)$ of the College tutors spend more than 20 hours a week on classroom teaching, while 45,2 percent spend between $11-20$ hours a week on this activity. Considerable time is also spent on individualised teaching, counselling, preparing lessons, setting and marking tests and examinations and administrative activities. Only one-quarter of the College tutors spend some time each week on clinical teaching and clinical assessment and almost two-third $(65,3 \%)$ spend less than 1 hour per week in visiting wards or community health facilities, while the remaining one third spend less than 5 hours per week on this activity.

\section{Enactment of scholarly role}

As so much time is spent on teaching activities, very little time is left for professional development and scholarly activity. More than 80 percent of College tutors spend less than 5 hours a week and almost 20 percent less than 1 hour a week on professional reading, while over 95 percent spend less than one hour a week on research or writing.

\section{Discussion}

From the findings it has become clear that the registered nurse tutor population of the 1980 's is a very heterogeneous population. The individual nurse tutor cannot therefore be represented by a stereotyped description of the registered nurse tutor. Among the population some were like their counterparts in some respects and dissimilar in others by gender, age, marital status, population group, place of employment, posts held, educational and professional background and experience.

Unlike the pre 1980's when the nurse tutor population was exclusively female, the registered nurse tutor population of the 1980 's is no longer exclusively sex-linked. A small percentage of males have availed themselves of the opportunity to qualify as tutors and have thus joined the ranks of the nurse tutor population. The important implication of this is that men can now also add their own critical, rational and empirical interest to nursing education, a contribution which may be considered conducive for a changing profession in a changing society with a need for a diversity of interests.

The majority of tutors were found to be chronologically mature women, with considerable experience. (The median age is 43,1 years). This should enable them to cope with the demands of the time. As almost two thirds of the tutors are marr and/or with dependants, it can be assun that the majority of nurse tutors occupy at least two very demanding roles, housewife and careerwoman, a development which employing authorities and the profession have virtually ignored, but which undoubtedly holds several implications for nursing education particularly with regard to continuing education and the scholarly role. More than two-fifths of the respondents cited family responsibilities and workload as major deterrent to continuing education. This finding is similar to those cited by Kretch et al. (1962: 496) that women who occupy the position of housewife and career woman frequently experience trouble and are unable to meet the status expectations of both roles. Because of the small percentage of single women in senior posts in the health services to-day, the services are not able to cope without the married woman. Authorities and leaders thus need to become sensitive to the loads carried by many of their staff members and institute plans to give the necessary support to those who may need it, so that they may be enabled to continue with the necessary studies. Continuing education is not only an individual and social responsibility of a professional in contemporary society, but a sine qua non. It is mainly through continuing education that the tutor becomes aware of her scholarly role, a requisite for tertiary educators, but which as the findings reveal, is still very neglected.

The finding that not even two-fifths of the respondents had at least a matriculation background in mathematics or science is a matter of concern, as many of the intricate modern technological devices and data which nurses are exposed to today, are difficult to understand and explain without the use of mathematical concepts. An ability to calculate and communicate mathematical and scientific information with accuracy is essential. Efforts should therefore be made to offer appropriate relevant remediation to those who may require it, or otherwise to 
organise the programme in such a way that tutors with insufficient mathematical background be placed in areas of teaching where a mathematical background is not required.

The concern of nurse leaders that nurse tutors have too limited a clinical experience was partially disproved, as eighty percent of respondents had had more than three years of clinical experience before registering as a tutor. This experience had been gained in many different fields. On the other hand, the concern that the contemporary nurse tutor may not be maintaining sufficient contact with the practical realities of the clinical situation, was partially justified, as only one-quarter of the respondents spent some time each week in the clinical field, while almost two-thirds spent less than one hour a week visiting clinical facilities.

The time factor appeared to be largely responsible for this, and also the organisation of the work schedule.

ention needs to be given to this

lation and possible contributory factors need to be identified and rectified. As far as her colleagues in other tertiary education institutions are concerned, it appears as though the nurse tutor of the 1980's has lagged behind, with regard to qualifications. A degree is a requirement for all colleagues in tertiary education posts. A considerable proportion of nurse tutors do not yet possess degrees. The findings however indicate that even though at the time of this study, only 47 percent of the respondents held at least a bachelors degree, another 22 percent were studying towards one. If this trend is continued, the gap should be closed in due time.

Judging from the profile identified with this study, there is no reason to believe that the contemporary nurse tutors cannot meet the challenge of tomorrow provided of course that they are given the time, a conducive climate and co-operatiion

\section{Limitations}

Even though every effort was made in the design and conduct of the study to obtain not only a random sample, but also a proportional stratified one to be representative of the total population as far as sex and population group was concerned, certain weaknesses in the study are apparent. As an example, the low response rate $(51,5$ percent of usable questionnaires) could have biased some of the findings. It may be assumed for instance that a greater proportion of tutors in possession of a degree as highest qualification than a diploma as highest qualification responded. This could have skewed the results toward a higher percentage of degreed people than there actually are in the total population. If this was the case it may also have influenced findings relating to aspects such as the scholarly role and other professional and educational experiences. Therefore the findings of this study cannot be considered absolutely conclusive or representative of the total tutor population. On the other hand the results obtained from an analysis of a further 21 questionnaires, which were received too late to be included in this study, revealed a similar trend. This makes the findings more credible. The findings may thus be regarded as an approximate data base of the total registered nurse tutor population in the RSA during 1984.

\section{Acknowledgement}

In conclusion I wish to acknowledge the financial assistance received from the Human Sciences Research Council in this study.

\section{BIBLIOGRAPHY}

Brink, H. 1984. The registered nurse tutor in the RSA. Doctoral thesis, UNISA: Pretoria.

Harrison, P.H. 1979. Salute to some nursing pioneers. Curationis, vol. 2, no. 2: 53-55.

In Memoriam, 1973. Miss Mary G. Milne, first sister tutor in South Africa. SA Nursing Journal, vol. XL, no. 4: 13

Krech, D. Crutchfield, R.S., Ballachey, E.L. 1962. Individual in Society. New York: McGraw-Hill.

Miss 1.1. Marwick leaves South Africa. 1968. $S A$ Nursing Journal, vol. XXXV, no. 7: 25 .

Searle, C. 1964(a). Testimony to fifty years of service. Pretoria: SANA

Searle, C. 1964 (b). The history of the development of nursing in South Africa, 1652-1960, Cape Town: Struik.

This article is based on part of the research undertaken in 1983 for the degree D. Litt. et Phil, with the University of South Africa.

H I I. Brink, D.Litt. et Phil., RN RM RT RNA Rc HN, Professor Dept. of Nursing Science, UNISA 